\title{
Oral administration of Bali Robusta coffee (Coffea canephora) extract prevented the reduction of Leydig cells and testosterone levels in male Wistar rats (Rattus norvegicus) with excessive physical training
}

Kandy Rosa Ismalia', Wimpie Pangkahila!, Ni Putu Sriwidyanil

IMaster Program in Biomedical Science, Concentration in Anti-Aging Medicine, Medical Faculty Udayana University, Bali, Indonesia

Cite this article:

Ismalia KR, Pangkahila W \& Sriwidyani NP. Oral administration of Bali Robusta coffee (Coffee canephora) extract prevented the reduction of Leydig cells and testosterone levels in male Wistar rats (Rattus norvegicus) with excessive physical training. Neurologico Spinale Medico Chirurgico. 202I.4(I):37-4I. DOI: I0.36444/nsmc.v4il.I5 I

Corresponding author:

Kandy Rosa Ismalia

Master Program in Biomedical Science, Concentration in Anti-Aging Medicine, Medical Faculty Udayana University, Bali, Indonesia. kandyrosa@yahoo.com

\begin{abstract}
Background: Excessive exercise cause a deterioration of organ function and structure. Overtraining will cause reduce antioxidant reserve and excess free radical production. In this condition, there will be a decrease in the number of Leydig cells in the testis and followed by a decrease in testosterone level. Bali robusta coffee extract contains active compounds such as alkaloids, saponins, flavonoids, tannins and polyphenols. This study aims to prove whether Bali robusta coffee extract (Coffea canephora) can prevent a decrease in the number of Leydig cells and testosterone levels in male Wistar rats (Rattus norvegicus) with excessive physical training.
\end{abstract}

Methods: Thirty-six rats were randomly divided into 2 groups: the control group (placebo aquabidest $2 \mathrm{ml}$ ) and the treatment group (Bali robusta coffee extract of 1 gram $/ \mathrm{kg} \mathrm{BW}$ ). Both groups received excessive physical training in the form of swimming until the subjects experienced fatigue for 21-days.

Results: The results showed that the mean of Leydig cell number in the treatment group was significantly higher, which was $3.70 \pm 0.89$ cell/field of view, compared to the control group, which was $2.92 \pm 0.65 \mathrm{cell} /$ field of view $(\mathrm{p}=0.005)$. The mean testosterone level in the treatment group was also significantly higher, which was $6.32 \pm 0.21 \mathrm{nmol} / \mathrm{ml}$, compared to the control group, which was $1.95 \pm 0.32 \mathrm{nmol} / \mathrm{ml}(\mathrm{p}<0.001)$.

Conclusion: The administration of Bali robusta coffee extract (Coffea canephora) prevented a decrease in the number of Leydig cells and testosterone levels in male Wistar rats (Rattus norvegicus) with excessive physical training.

Keywords: Bali Robusta coffee extract, Leydig cells, Testosterone, Overtraining

\section{Introduction}

Aging is a time-dependent adaptation that ultimately becomes maladapted (dysregulated), no longer obeying the principle of hormesis and leading to self-elimination and death. However, 
along with the development of science, especially in the field of Medicine, aging is considered as a disease that can be avoided, prevented and slowed down with various efforts based on evidencebased medicine. The aging process that is left untreated or an attempt to restore it to its original function can reduce the quality of life so that it can accelerate the aging process. ${ }^{1}$

One of the factors that cause aging is the accumulation of oxidative damage caused by high levels of free radicals in the body. Free radicals can be triggered by stress or excessive physical training., ${ }^{2,3}$ The underlying mechanism is the excessive physical activity can increase oxygen consumption by 100-200 times. ${ }^{4}$ Physiologically, 2$5 \%$ of the oxygen used during the metabolic process will be converted to superoxide, which will trigger oxidative stress and can damage all cells in the body including Leydig cells. ${ }^{5}$

Leydig cell apoptosis due to overtraining is mediated by the free radicals-induced oxidative damage. The association between apoptosis and Leydig cells has been previously reported in experimental animals. ${ }^{6}$ The induction of apoptosis in Leydig cells due to free radicals is mediated by the activation of the intrinsic pathway of apoptosis ${ }^{7}$, the p53-independent pathway, the induction of autophagy ${ }^{6}$, and endoplasmic reticulum stress. ${ }^{8}$ Because Leydig cells produce testosterone through a process known as steroidogenesis ${ }^{9}$, the death of Leydig cells due to excessive physical training can cause a decrease in testosterone levels which leads to aging and infertility. Previous studies reported that 21 days of overtraining in 24-year-old men can reduce testosterone levels. ${ }^{10}$ Testosterone is one of the essential hormones whose levels decrease due to aging, and vice versa, decreased testosterone levels can accelerate the aging process. ${ }^{1}$ Hence, efforts to prevent a decrease in the number of Leydig cells and a decrease in testosterone levels due to excessive physical training are important Anti-Aging Medicine steps. ${ }^{11}$

Because the pathogenesis of overtraining is mediated by free radicals, antioxidants administration may serve as a step to prevent the pathogenesis of overtraining. ${ }^{12}$ Coffee is a fairly high source of polyphenols. The polyphenol content in coffee includes caffeine, chlorogenic acid, coumaric acid, ferulic acid, and synapat acid. ${ }^{13}$ In addition, the phytochemical analysis showed that the Bali Robusta coffee extract used in this study contains a flavonoid of 9,203.34 $\mathrm{mg} / 100 \mathrm{~g}$, total phenols of 79,325.95 mg/100g, tannin of 27,532.06 mg/100g, and IC50 of 98.42 ppm (unpublished data).

Previous research has also shown excellent antioxidant activity, where Bali Robusta coffee a dose of $0.5 \mathrm{mg} / 200 \mathrm{~g}$ BW for 21 days can significantly prevent the elevation of malondialdehyde (MDA) levels of hyperuricemic rats. ${ }^{14}$ Other studies have also shown that the antioxidant activity of Bali Robusta coffee extract increased the total antioxidant status in metabolic syndrome rats. ${ }^{15}$ This study aimed to prove whether Bali Robusta coffee extract (Coffea canephora) can prevent a decrease in the number of Leydig cells and testosterone levels in male Wistar rats (Rattus norvegicus) with excessive physical training.

\section{Methods}

This research was an experimental study, using the posttestonly control group design. The subjects of this study were healthy male rats (Rattus norvegicus), 6 months old, and 200 grams in weight. Thirtysix rats were randomly divided into 2 groups. The control group was the male Wistar rat group given a placebo aquabidest $2 \mathrm{ml}$ once a day. The treatment group was the male Wistar rat group given Bali Robusta coffee extract at a dose of 1 gram $/ \mathrm{kg}$ BW/day dissolved in $2 \mathrm{ml}$ aquabidest. Both groups received excessive physical training in the form of swimming until the subjects experienced fatigue. After 21 days of treatment, blood samples were taken for testing of testosterone and testis was taken for examination of the number of Leydig cells using by evaluation of histologic slides stained with Hematoxylin Eosin. The mean difference of Leydig cell number and testosterone level between groups was tested using an independent T-test with 0.05 significance.

\section{Results}
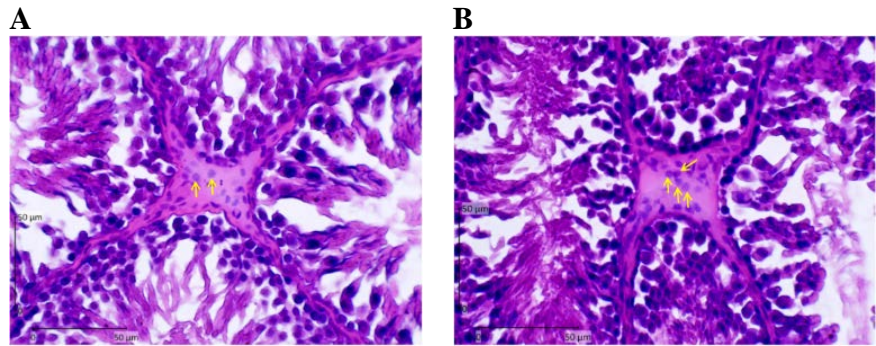

Figure 1. Examination Leydig cell histology. (A) control group and (B) treatment group. The number of Leydig cells in the treatment group is greater than the control group

The number of Leydig cells was examined histologically on testicular tissue samples. The calculation was carried out by observing the number of Leydig cells in the right and left testicles in three fields of view in a zig-zag direction, with a magnification of 400 times then the results obtained were averaged. ${ }^{16}$ The histology of the testicular tissue after HE stains is shown in Figure 1. The results showed that the mean of Leydig cell number in the treatment group was significantly 
higher, which was $3.70 \pm 0.89$ cell/field of view, compared to the control group, which was $2.92 \pm 0.65$ cell/ field of view ( $\mathrm{p}=0.005)$. The mean testosterone level in the treatment group was also significantly higher, which was $6.32 \pm 0.21 \mathrm{nmol} / \mathrm{ml}$, compared to the control group, which was $1.95 \pm 0.32 \mathrm{nmol} / \mathrm{ml}(\mathrm{p}<0.001)$.

Table 1. Comparison of Leydig cells number and testosterone levels

\begin{tabular}{llcccc}
\hline \multicolumn{1}{c}{ Variable } & Group & n & Mean \pm SD & P & Description \\
\hline $\begin{array}{l}\text { Leydig Cells } \\
\text { (cells/field of }\end{array}$ & Control & 18 & $2.92 \pm 0.65$ & & \\
view) & Treatment & 18 & $3.70 \pm 0.89$ & 0.005 & Significant \\
$\begin{array}{l}\text { Testosterone } \\
(\mathrm{nmol} / \mathrm{ml})\end{array}$ & Control & 18 & $1.95 \pm 0.32$ & 0.000 & Significant \\
\hline
\end{tabular}

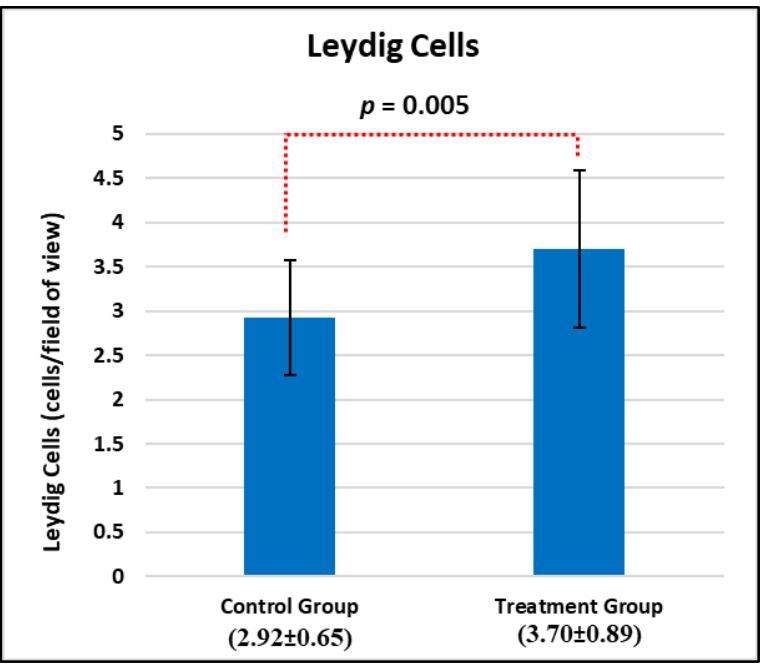

Figure 2. Graphical comparison of Leydig cells number

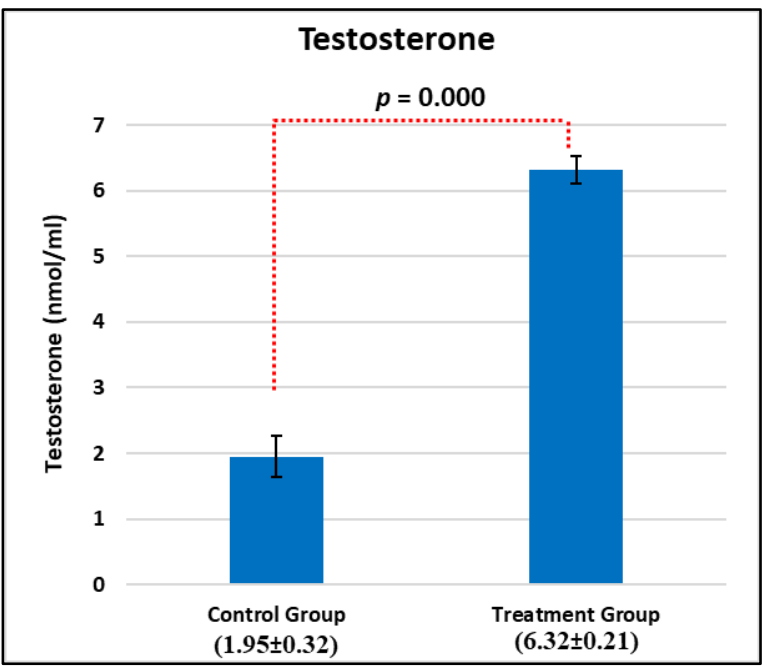

Figure 3. Graphical comparison of testosterone levels

\section{Discussion}

\section{The effect of Bali Robusta Coffee extract on the number of Leydig cells}

The results of this study indicated that the Bali Robusta coffee extract can prevent declining Leydig cells in young Wistar rats treated with overtraining. The number of Leydig cells in the treatment group was higher than the control group because coffee contains active compounds such as alkaloids, saponins, flavonoids, and polyphenols. ${ }^{17,18}$ Likewise, a study showed that coffee contains tannins, alkaloids, flavonoids, coumarin, quinones, phenols and essential oils. ${ }^{19}$

Flavonoids are oxidized by radicals, resulting in more stable and less reactive radicals. Flavonoids consist of two aromatic rings attached to three carbons and are usually in the oxygenated heterocyclic form. Flavonoids will inhibit the aromatase enzyme, which is an enzyme that catalyzes the conversion of androgens to estrogen that will increase the testosterone and eventually the number of Leydig cells. ${ }^{20}$

Polyphenol compounds are plant secondary metabolites derived from a biosynthetic pathway with precursors from the cyclic and/or acetate-malonate pathways. The function of these metabolites is to protect plants from biological and environmental stress. Therefore, these compounds are synthesized to respond to pathogens such as fungi or bacteria. Phenols can function as primary antioxidants because they can directly inhibit free radical reactions to lipid oxidation. ${ }^{21}$

Tannins have antioxidant activity, inhibit tumor growth, and inhibit enzymes such as reverse transcriptase and DNA topoisomerase. Tannins also induce the proliferation and division of Leydig cells and increase the number of Leydig cells in the testicular interstitial tissue. ${ }^{22}$

\section{The effect of Bali Robusta Coffee extract on testosterone levels}

The results of this study showed that Bali coffee prevents the decrease in testosterone levels caused by overtraining. Leydig cells are the main testosterone-producing cells in men and male animals, so an increase in the number of Leydig cells has a direct impact on increasing testosterone levels. ${ }^{23}$ Normal levels of testosterone in adult rats are 0.5 $5.4 \mathrm{ng} / \mathrm{ml}^{24}$, and in this study, the testosterone level were $1.95 \pm 0.32$ and $6.32 \pm 0.21 \mathrm{nmol} / \mathrm{L}$ for the control and treatment group respectively. So that the two groups are still classified as having normal testosterone levels.

Flavonoids can increase testosterone levels by inhibiting the 5alpha reductase enzyme, which converts testosterone to 
dihydrotestosterone and increases testosterone levels. ${ }^{25}$ Study reported that flavonoids are a class of compounds that function as antiandrogenic by blocking the work of the aromatase enzyme, where this enzyme serves to catalyze the conversion of androgens to estrogens resulting in the elevation of the testosterone hormone. ${ }^{20}$ Flavonoids can also stabilize reactive oxygen compounds by reacting with the reactive arrangement of these radicals. ${ }^{26}$

Tannins may increase testosterone levels through an increase in the number of Leydig cells due to MAPK activation. ${ }^{27}$ To date, there have been no studies showing a direct effect of tannins on the activity of testosterone synthesis in Leydig cells or the adrenal cortex. Tannins affect biological activity that can coagulate protein, it is suspected that the enzyme protein (ATPase/dynein) is damaged, so that the energy release mechanism for spermatozoa motility will be disrupted. ${ }^{28}$ So that if the tannin levels are sufficient, the amount of testosterone will also be well preserved and not decrease.

\section{Relationship of Bali Robusta Coffee extract with anti-aging medicine}

Excessive physical training is defined as excess exercise volume, intensity, duration, or burden. ${ }^{3}$ Many studies have shown that overtraining can lead to oxidative stress. Because Leydig cells are cells that produce testosterone ${ }^{9}$, the Leydig cells apoptosis cause a decrease in testosterone. ${ }^{10}$ Testosterone is an important hormone whose levels decrease due to aging and vice versa. ${ }^{1}$ So efforts to prevent a decrease in the number of Leydig cells and a decrease in testosterone levels due to excessive physical training are important Anti-Aging Medicine steps, especially for community groups who are vulnerable to excessive physical activity such as athletes, police and soldiers. ${ }^{11}$ The administration of Bali Robusta coffee extract ameliorated the overtraining-induced declining Leydig cels and testosterone, thus supporting the concept of anti-aging medicine.

\section{Conclusion}

The conclusion of this study was that the administration of Bali Robusta coffee extract (Coffea canephora) prevented a decrease in the number of Leydig cells and testosterone levels in male Wistar rats (Rattus norvegicus) with excessive physical training. It is necessary to compare the effectiveness of Bali Robusta coffee extract with other compounds to find out which natural ingredients are best in preventing the decrease in testosterone levels and Leydig cells. Additionally, further research to determine the potential toxicity of this coffee extract is required.

\section{References}

1. Pangkahila W. Anti-aging medicine: Memperlambat penuaan, meningkatkan kualitas hidup. 2nd ed. P:54, Jakarta: Penerbit Buku Kompas; 2017.

2. Pham-Huy LA, He H, Pham-Huy C. Free radicals, antioxidants in disease and health. Int J Biomed Sci. 2008;4(2):89-96.

3. Kartiko BH, Siswanto FM. Overtraining elevates serum protease level, increases renal p16INK $4 \alpha$ gene expression and induces apoptosis in rat kidney. Sport Sci Health. 2018;14(2):331-337. DOI: 10.1007/s11332018-0433-6

4. Irtanto O, Pangkahila AJ, Aman IGM. Pemberian ekstrak floret pisang raja (Musa x paradisiaca) mencegah penurunan kadar superoksida dismutase (SOD) pada hati mencit (Mus musculus) BALB/c dengan aktivitas fisik berlebih. Jurnal Biomedik (JBM). 2017;9(3):166-171. DOI: 10.35790/jbm.9.3.2017.17338

5. Xu G, Zhao J, Liu H, et al. Melatonin inhibits apoptosis and oxidative stress of mouse Leydig cells via a SIRT1-dependent mechanism. Molecules. 2019;24(17):3084. DOI:10.3390/molecules24173084

6. Wang Y, Zheng W, Bian X, et al. Zearalenone induces apoptosis and cytoprotective autophagy in primary Leydig cells. Toxicol Lett. 2014;226(2):182-91. DOI: 10.1016/j.toxlet.2014.02.003

7. He Z, Simon HU. A novel link between p53 and ROS. Cell Cycle. 2013;12(2):201-2. DOI: 10.4161/cc.23418

8. Lin PF, Chen FL, Sun J, et al. Mycotoxin zearalenone induces apoptosis in mouse leydig cells via an endoplasmic reticulum stressdependent signalling pathway. Reprod Toxicol. 2015;52:71-77. DOI: 10.1016/j.reprotox.2015.02.007

9. Salerno M, Cascio O, Bertozzi G, et al. Anabolic androgenic steroids and carcinogenicity focusing on Leydig cell: A literature review. Oncotarget. 2018;9(27):19415-19426. DOI: 10.18632/oncotarget.24767

10. Slivka DR, Hailes WS, Cuddy JS, et al. Effects of 21 days of intensified training on markers of overtraining. $J$ Strength Cond Res. 2010;24(10):2604-12. DOI: 10.1519/JSC.0b013e3181e8a4eb

11. Pangkahila EA, Siswanto FM. Pola hidup tidak teratur dan aktivitas fisik berlebih menurunkan kemampuan aktivitas seksual. Sport and Fitness Journal. 2015;3(1):59-69.

12. Yavari A, Javadi M, Mirmiran P, et al. Exercise-induced oxidative stress and dietary antioxidants. Asian J Sports Med. 2015;6(1):e24898. DOI:10.5812/asjsm.24898

13. Hečimović I, Belščak-Cvitanović A, Horžić D, et al. Comparative study of polyphenols and caffeine in different coffee varieties affected by the degree of roasting. Food Chem. 2011;129(3):991-1000. DOI: 10.1016/j.foodchem.2011.05.059 
14. Dewajanti A, Sumbayak E, Neno M. Uji aktivitas antioksidan infusa biji kopi Arabika (Coffea arabica L.): Pengukuran kadar malondialdehid (MDA) pada tikus Wistar (Rattus novergicus) hiperurisemia. Jurnal Kedokteran Meditek. 2019;24(68):28-35. DOI:10.36452/jkdoktmeditek.v24i68.1699

15. Widyastuti N, Anjani G, Almira VG, et al. Effects of the administration of brewed Robusta coffee leaves on total antioxidant status in rats with high-fat, high-fructose diet-induced metabolic syndrome. Potravinarstvo Slovak Journal of Food Sciences. 2020;14:258-263. DOI:10.5219/1350

16. Siswanto FM, Pradhany RC, Yenniastoeti BP, et al. Ethanolic extract of black grapes (Vitis Vinifera) ameliorates overtraining-induced pancreatic $\beta$-cells and muscle damage. Jurnal Riset Veteriner Indonesia (Journal of The Indonesian Veterinary Research). 2020;4(2):69-75. DOI:10.20956/jrvi.v4i2.9688

17. Nehlig A. Is caffeine a cognitive enhancer?. Journal of Alzheimer's Disease. 2010;20 Suppl 1:S85-94. DOI: 10.3233/jad-2010-091315

18. Di Castelnuovo A, di Giuseppe R, Iacoviello L, et al. Consumption of cocoa, tea and coffee and risk of cardiovascular disease. Eur J Intern Med. 2012;23(1):15-25. DOI: 10.1016/j.ejim.2011.07.014

19. Siswanto FM, Oguro A, Imaoka S. Chlorogenic acid modulates hypoxia response of Hep3B cells. Personalized Medicine Universe. 2017;6:12-16. DOI: 10.1016/j.pmu.2017.03.0011

20. Oliveira GA, Ferraz ER, Souza AO, et al. Evaluation of the mutagenic activity of chrysin, a flavonoid inhibitor of the aromatization process. $J$ Toxicol Environ Health A. 2012;75(16-17):1000-11. DOI: 10.1080/15287394.2012.696517
21. Ding S, Jiang H, Fang J. Regulation of immune function by polyphenols. $J \quad$ Immunol Res. 2018;2018:1264074. DOI:10.1155/2018/1264074

22. Ismail $\mathrm{T}$, Calcabrini $\mathrm{C}$, Diaz $\mathrm{AR}$, et al. Ellagitannins in cancer chemoprevention and therapy. Toxins (Basel). 2016;8(5):151. DOI: 10.3390/toxins8050151

23. Pangkahila W, Wih LP. Evidence-based anti-aging medicine hormone replacement therapy. 1st ed. P:51. TLC Publication: Singapore. 2015.

24. El-Migdadi F, Qaw F. Serum and plasma levels of total and free testosterone and of sex hormone binding globulins in rats growing in the below sea level environment of the Jordan valley. Journal of Endocrinology. 2008;5(2):1-7.

25. Azarneoshan F, Khatam SS, and Sadeghi H. The effects of hydro alcoholic extract of dorema aucheri on blood concentration of gonadotropin and androgen hormones in adult male rats. Armaghane Danesh. 2009;14(3):63-70.

26. Procházková D, Boušová I, Wilhelmová N. Antioxidant and prooxidant properties of flavonoids. Fitoterapia. 2011;82(4):513-23. DOI: 10.1016/j.fitote.2011.01.018

27. Yesudas R, Gumaste U, Snyder R, et al. Tannic acid down-regulates the angiotensin type 1 receptor through a MAPK-dependent mechanism. Mol Endocrinol. 2012;26(3):458-70. DOI: 10.1210/me.2011-1224

28. Fraga-Corral M, García-Oliveira P, Pereira AG, et al. Technological application of tannin-based extracts. Molecules. 2020;25(3):614. DOI: 10.3390/molecules25030614 